\title{
Production of anorthite refractory insulating firebrick from mixtures of clay and recycled paper waste with sawdust addition
}

\author{
Mucahit Sutcu $^{\mathrm{a}, *}$, Sedat Akkurt $^{\mathrm{b}}$, Alican Bayram ${ }^{\mathrm{b}}$, Uluc Uluca ${ }^{\mathrm{b}}$ \\ ${ }^{a}$ Metallurgical and Materials Engineering Department, Bartin University, 74100 Bartin, Turkey \\ ${ }^{\mathrm{b}}$ Mechanical Engineering Department, Izmir Institute of Technology, 35430 Izmir, Turkey \\ Received 16 June 2011; accepted 11 August 2011 \\ Available online 19 August 2011
}

\begin{abstract}
Production of porous anorthite refractory insulating firebricks from mixtures of two different clays (K244 clay and fireclay), recycled paper processing waste and sawdust addition are investigated. Suitability of alkali-containing-clay, low-alkali fireclay, pore-making paper waste and sawdust in the products was evaluated. Prepared slurry mixtures were shaped, dried and fired. Highly porous anorthite ceramics from the mixtures with up to $30 \%$ sawdust addition were successfully produced. Physical properties such as bulk density, apparent porosity, percent linear change were investigated as well as the mechanical strengths and thermal conductivity values of the samples. Thermal conductivities of the samples produced from fireclay and recycled paper waste decreased from $0.25 \mathrm{~W} / \mathrm{mK}\left(1.12 \mathrm{~g} / \mathrm{cm}^{3}\right)$ to $0.13 \mathrm{~W} / \mathrm{mK}\left(0.64 \mathrm{~g} / \mathrm{cm}^{3}\right)$ with decreasing density. Samples were stable at high temperatures up to $1100{ }^{\circ} \mathrm{C}$, and their cold strength was sufficiently high. The porous anorthite ceramics produced in this study can be used for insulation in high temperature applications.
\end{abstract}

(C) 2011 Elsevier Ltd and Techna Group S.r.l. All rights reserved.

Keywords: Porosity; Thermal conductivity; Anorthite; Refractories; Recycled paper waste

\section{Introduction}

Insulating firebricks (IFBs) constitute one of the refractory groups which are most commonly used for heat insulation in industrial applications today. They are highly porous and lightweight refractories having much lower thermal conductivity and heat capacity than other refractories [1]. Different types of insulating firebricks are mainly manufactured by using the raw materials such as diatomite, perlite, expanded vermiculite, calcium silicate, fireclay, kaolin, quartz, alumina and lightweight refractory aggregates by conventional methods $[1,2]$. Porosity is usually created by adding a combustible material to the raw material mixture. During firing, the combustible material burns out, and leaves a large fraction of pores within the fired body. Different types of pore-formers such as sawdust, foam polystyrene, fine coke, binders and organic foams, or granular materials such as hollow micro-

\footnotetext{
* Corresponding author. Tel.: +90 378223 5360; fax: +90 3782235258.

E-mail addresses: msutcu@bartin.edu.tr (M. Sutcu), sedatakkurt@iyte.edu.tr (S. Akkurt), alican@iyte.net (A. Bayram), uluculuca@std.iyte.edu.tr (U. Uluca).
}

spheres and bubble alumina are commonly used to obtain decreased density or to produce porous bodies in the insulating material [2-8]. Insulating firebricks that have a highly porous structure (between $45 \%$ and $90 \%$ porosity) exhibit low thermal conductivity values. The thermal conductivity not only depends on their total porosity, but also their pore size and shape, chemical and mineralogical composition [2,5].

Insulating firebricks are classified by ASTM according to the bulk density and maximum service temperature [9]. For example, the groups 20 and 23 with high $\mathrm{CaO}$ content represent the anorthite $\left(\mathrm{CaO} \cdot \mathrm{Al}_{2} \mathrm{O}_{3} \cdot 2 \mathrm{SiO}_{2}\right)$ based insulating firebricks with maximum temperature limits of 1093 and $1260{ }^{\circ} \mathrm{C}$, respectively. Anorthite insulating firebricks are mainly manufactured from mixtures of clay, gypsum $\left(\mathrm{CaSO}_{4} \cdot 2 \mathrm{H}_{2} \mathrm{O}\right)$ binder and sawdust [3]. The mixture hardens after forming and is fired. A porous ceramic is produced with combustion of the sawdust. However, an important problem of this method is environmentally the release of sulfur compounds from gypsum, which is highly undesirable. In the early works, some researchers developed the low density anorthite refractories using kaolin and gypsum slurry mixtures $[3,7]$. In these products, several different pore making agents like perlite foam, sawdust and polystyrene have been used [3,7]. 
Recently, there has been considerable research on the reuse of pulp and paper industry wastes as a new source of raw material or pore-former in the ceramic materials due to their organic and inorganic contents [10-15]. A patent was reported on how to produce low density ceramics from paper recycling residuals [11]. This invention describes that produced ceramics can be used for high temperature applications as insulating materials and filtration devices. However, in this invention, the intervals of parameters for producing ceramics are not sufficiently defined. In a previous study by authors [15], production of porous anorthite ceramics from mixtures of paper processing residues and three different clays (enriched clay, K244 clay and fireclay) were investigated. Paper processing residues composed of calcium carbonate (as $\mathrm{CaO}$ source) and fine cellulose fibers (as pore former) were used as an additive to clay raw materials to make porous anorthite ceramic. The study showed that anorthite formation for all clay types was quite successful in samples with 30 and $40 \mathrm{wt} \%$ of paper residues fired at $1300{ }^{\circ} \mathrm{C}$.

In this study, porous anorthite insulating firebricks have been developed by adding recycled paper processing wastes and sawdust to two different types of clay. The addition of recycled paper waste as source of $\mathrm{CaO}$ into a clay system enables us to form anorthite composition. Also a micro-porous structure of the fired bodies forms due to the burning of cellulose fibers and decomposition of calcium carbonate while the addition of sawdust to the mixtures produces macro-porosity.

\section{Experimental procedure}

In this study, production of anorthite based insulating firebrick was accomplished from mixtures of two different clays, recycled paper processing waste and sawdust. Commercial K244 clay (Kalemaden, Turkey) and ground fireclay (Eczacıbaş1 Esan, Turkey) were used as $\mathrm{Al}_{2} \mathrm{O}_{3}$ and $\mathrm{SiO}_{2}$ supplies, while recycled paper waste (Levent Kağ $t$ t, Turkey) was used as a source of calcium oxide to attain anorthite $\left(\mathrm{CaO} \cdot \mathrm{Al}_{2} \mathrm{O}_{3} \cdot 2 \mathrm{SiO}_{2}\right)$ synthesis. Another important property of this waste is pore-making effect during firing due to its cellulose fiber and $\mathrm{CaCO}_{3}$ content. The physical, chemical and thermal properties of the raw materials were previously characterized.

Anorthite based rectangular samples $(20 \mathrm{~mm} \times 60 \mathrm{~mm} \times$ $150 \mathrm{~mm}$ ) were formed by a slurry casting process. In order to increase the amount of porosity in the samples, wooden sawdust with particle size smaller than $3 \mathrm{~mm}$ was used as burnout pore-making additive as well as the paper waste. The mixtures containing clay and $30 \mathrm{wt} \%$ paper waste (on dry basis) that supplied the strongest anorthite composition [15] were prepared for production of the samples. Recycled paper processing waste was in sludge form. The paper waste was dispersed into water and was mixed with the selected clay. Then, the sawdust (10 wt $\%, 20 \mathrm{wt} \%$ and $30 \mathrm{wt} \%$ ) was added into these mixtures at certain ratios of the total mixtures. Water addition was made into the mixtures to decrease viscosity of the sludge to compensate for the reduction in flow after sawdust addition. Total water content of mixtures varied from 55 to $66 \%$ depending on the amount of sawdust. The slurry mixtures for casting that had a consistency of a thick cream, were prepared in a mechanical mixer and were stirred for 30 minutes (Heidolph RZR-2020). Viscosities of the slurries were measured by a Brookfield Viscometer (DV II + Pro). The slurry mixtures were cast into hardboard molds $(80 \mathrm{~mm} \times 160 \mathrm{~mm})$ placed onto plaster blocks. The plaster suctioned excess water by capillary. In the meantime, top surface of the slurry was compressed by hand in order to ensure complete filling of the mold. Green samples were removed from the mold after 1-2 $\mathrm{h}$ and were left to dry in ambient conditions for 24-72 h depending on clay-type and water content. Cellulose fibers in the paper sludge helped to improve the strength of the green samples. Samples were further dried in an oven maintained at $50{ }^{\circ} \mathrm{C}$ for $12 \mathrm{~h}$ and then at $100{ }^{\circ} \mathrm{C}$ for $24 \mathrm{~h}$. According to the type of clay used, dry samples were fired at $1200{ }^{\circ} \mathrm{C}$ (for K244 clay) and $1300{ }^{\circ} \mathrm{C}$ (for fireclay) for $1 \mathrm{~h}$ in a laboratory-type electrical kiln (Protherm, Turkey). The heating rate was $2.5^{\circ} \mathrm{C} / \mathrm{min}$ until $600{ }^{\circ} \mathrm{C}$, and $10^{\circ} \mathrm{C} / \mathrm{min}$ until the dwell temperatures. Firing temperatures used in this study $\left(1200\right.$ and $1300{ }^{\circ} \mathrm{C}$ ) were $100{ }^{\circ} \mathrm{C}$ lower than those predicted in a
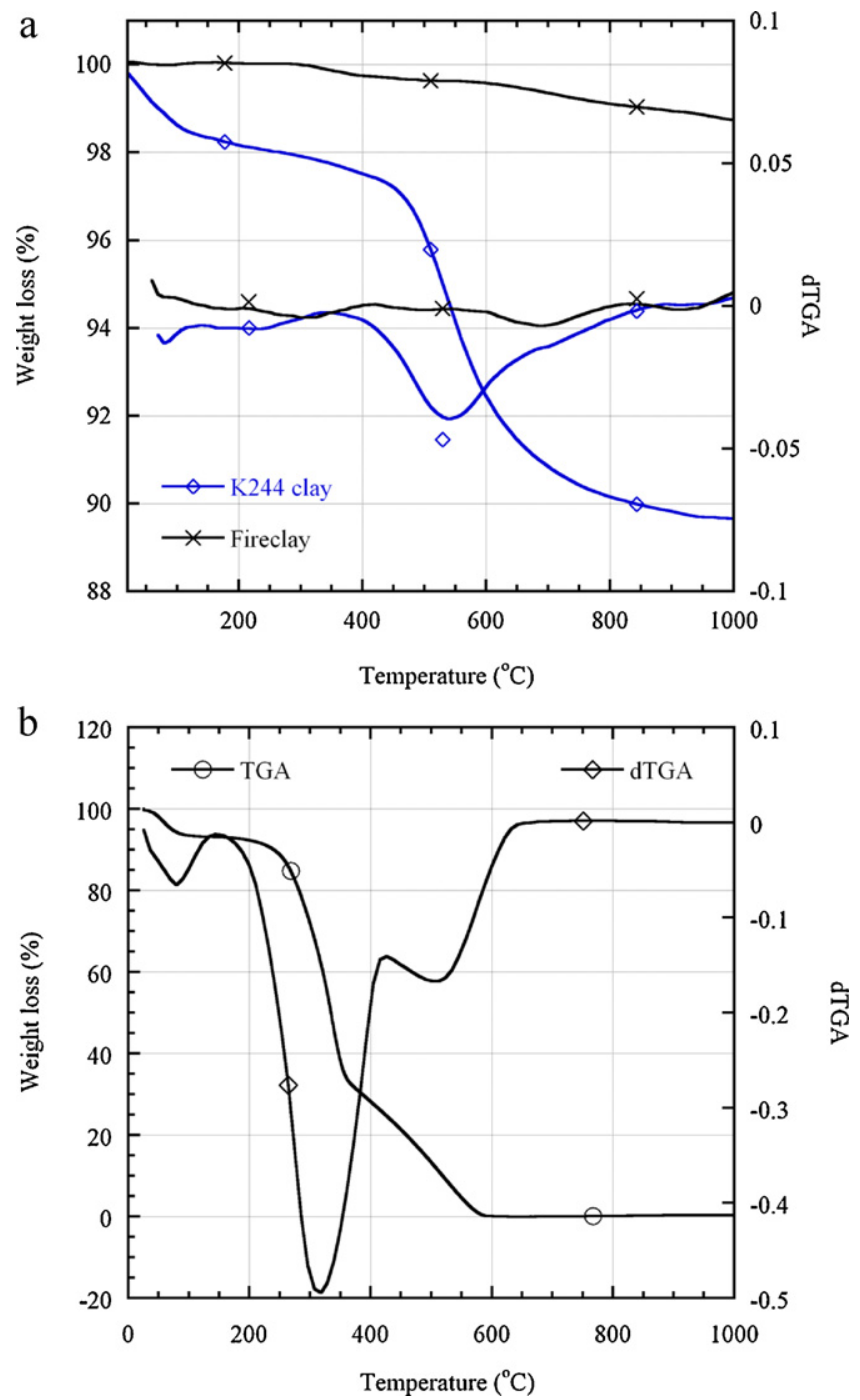

Fig. 1. Thermo-gravimetric analysis of (a) the clays and (b) sawdust. 
previous study of the authors [15]. This was because the sawdust addition was expected to supply additional heat to the sample during firing and hence samples may warp due to premature melting. Pure anorthite melts congruently at $1553{ }^{\circ} \mathrm{C}$ according to the $\mathrm{Al}_{2} \mathrm{O}_{3}-\mathrm{SiO}_{2}-\mathrm{CaO}$ phase system although this may be lowered due to impurities present in the raw materials.

The crystalline phases in the firebricks were investigated by using X-ray diffraction (XRD, Philips X'Pert Pro). Microstructural analysis of the samples was performed by using scanning electron microscope (SEM, Philips XL-30SFEG) and energy dispersive X-ray analysis (EDAX). ASTM C134 standard test method was used for measuring the weight, dimensional measurements and bulk density of the produced bricks [16]. Apparent porosity measurements of the samples were performed by boiling water immersion for $2 \mathrm{~h}$ and soaking in water for $24 \mathrm{~h} \mathrm{[17].}$

The coefficients of thermal expansion (CTE) of the samples were measured by a horizontal dilatometer (Linseis, Germany). Small sized samples $(8 \mathrm{~mm} \times 8 \mathrm{~mm} \times 16 \mathrm{~mm})$ were cut from the larger fired samples to be used for dilatometric test. Also, the CTE values of the samples were linearly calculated from slope of shrinkage versus temperature. Thermal conductivity measurements were employed on $20 \mathrm{~mm} \times 60 \mathrm{~mm} \times 150 \mathrm{~mm}$ sized samples at room temperature $\left(\sim 30^{\circ} \mathrm{C}\right)$ by hot-wire method using the Quick Thermal Conductivity Meter (QTM500, Kyoto Electronics). A mechanical test was applied to determine the cold modulus of rupture (MOR) of the fired samples. The cold strength of a refractory material is an indication of its suitability for use in refractory construction. According to ASTM C133-97, the preferred test specimens should be $228 \mathrm{~mm} \times 114 \mathrm{~mm} \times 76 \mathrm{~mm}$ bricks or specimens of equivalent size cut from refractory shapes [18]. In this study, these brick sizes were impossible in the laboratory, so alternative specimen sizes of $45 \mathrm{~mm} \times 22.5 \mathrm{~mm} \times 15 \mathrm{~mm}$ were prepared by cutting 5 times smaller samples from the larger fired samples. For the MOR test, a mechanical test machine (Shimadzu AGS-J $5 \mathrm{kN}$ ) with three-point bending apparatus was used. In this test, span interval and strain rate was $35 \mathrm{~mm}$ and $1 \mathrm{~mm} / \mathrm{min}$, respectively. Thermal shock tests were also performed on samples to find out their resistance to repeated heating and cooling cycles by heating to $1200{ }^{\circ} \mathrm{C}$ and cooling to room temperature in five cycles [19].

\section{Results and discussion}

\subsection{Characterization of the raw materials and slurry mixtures}

The recycled paper waste was obtained from a local paper manufacturer (Levent Kağıt A.Ş.) that produced paper from recycled paper. The waste had about $65 \%$ water content. Solid part of this waste contained about $40 \%$ organic matter (cellulose fiber) and 60\% inorganic components like calcite and other clayey materials. Physical, chemical and thermal properties of the paper waste are presented in a previous publication of the authors [14]. Fireclay was selected as the clay raw material for high refractoriness of the products. Chemical composition of fireclay consisted of $59 \% \mathrm{SiO}_{2}, 38.5 \% \mathrm{Al}_{2} \mathrm{O}_{3}$, $1.1 \% \mathrm{TiO}_{2}, 0.5 \% \mathrm{Fe}_{2} \mathrm{O}_{3}, 0.4 \% \mathrm{~K}_{2} \mathrm{O}, 0.1 \% \mathrm{CaO}, 0.1 \% \mathrm{MgO}$ and $0.05 \% \mathrm{Na}_{2} \mathrm{O}$ [20]. Its X-ray analysis result showed the presence of quartz, mullite and cristobalite phases. K244 clay with alkali included 59.1\% $\mathrm{SiO}_{2}, 26.9 \% \mathrm{Al}_{2} \mathrm{O}_{3}, 0.8 \% \mathrm{TiO}_{2}, 1.5 \% \mathrm{Fe}_{2} \mathrm{O}_{3}$, $2.2 \% \mathrm{~K}_{2} \mathrm{O}, 0.3 \% \mathrm{CaO}, 0.6 \% \mathrm{MgO}$ and $0.04 \% \mathrm{Na}_{2} \mathrm{O}$ [21]. The mineral content of K244 clay was mainly quartz and kaolinite with some illite. Thermo-gravimetric analysis curves of the clays and sawdust are shown in Fig. 1. Loss on ignition values of K244 clay and fireclay were measured as $10 \%$ and $1 \%$, respectively. The largest weight loss occurred between 500 and
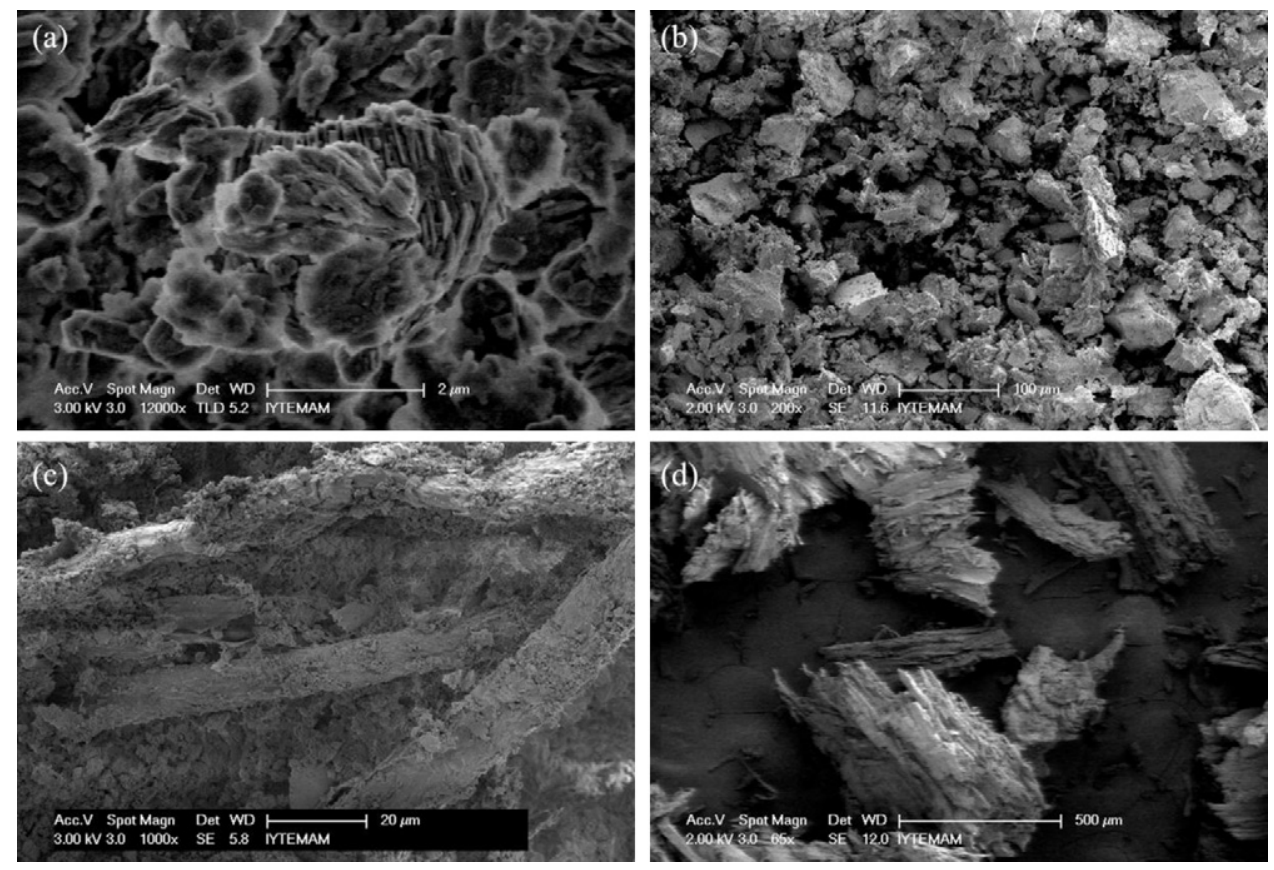

Fig. 2. The SEM images at different magnifications of (a) clay 244, (b) fireclay (chamotte), (c) paper waste and (d) wood sawdust additives. 
$700{ }^{\circ} \mathrm{C}$ during heating of $\mathrm{K} 244$ clay. It is attributed to dehydroxylation of kaolin to form metakaolin and dehydroxylation of illite due to the disruption of structural hydroxyl groups in clay. The main components of wood sawdust are hemicellulose, cellulose, and lignin, and these components are decomposed at different temperature ranges [22]. The TGA results of the sawdust showed that the moisture loss (about 5\%) took place up to $100{ }^{\circ} \mathrm{C}$ followed by pyrolysis. Then the major weight loss (about 65\%) is due to the fast decomposition of hemicellulose and cellulose at $180-350{ }^{\circ} \mathrm{C}$. After rapid pyrolysis, relatively slow pyrolysis occurred over $350{ }^{\circ} \mathrm{C}$, and the second weight loss (about 30\%) caused by the lignin decomposition. The SEM images at different magnifications of clay 244, fireclay (chamotte), paper waste and wood sawdust additive are shown in Fig. 2, respectively. In Fig. 2c, microsized cellulose fibers in the waste obviously are shown. Sizes of the sawdust were between 0.5 and $1 \mathrm{~mm}$.

The viscosities of the sludge mixtures containing clay and paper waste with sawdust addition were measured. Fig. 3(a) and (b) shows the viscosity as a function of rotational speed of the spindle for the slurries containing fireclay and K244 clay with paper waste at different sawdust additions, respectively. A shear thinning behavior was observed for the slurries containing either fireclay or K244 clay, such that viscosity is reducing with the increase of rotational speed of the spindle. The viscosity of the slurries containing K244 clay is relatively higher than that of the slurries containing fireclay. This is related with their particle size and surface area, and also the type of the clays. The particle size of K244 clay $(<5 \mu \mathrm{m})$ was lower than that of the fireclay $(<45 \mu \mathrm{m})$ meaning that the reactivity of the former can be expected to be higher than the latter.

\subsection{Fired samples containing K244 clay and paper waste mixture with sawdust addition}

In the previous study by the authors [15], the detailed XRD analysis results of the samples were given for samples containing K244 clay and $30 \mathrm{wt} \%$ paper waste mixture that were fired at different temperatures. Mainly anorthite phase and a minor amount of quartz were observed in the samples fired at $1200{ }^{\circ} \mathrm{C}$. Quartz was completely dissolved at higher temperature over $1200{ }^{\circ} \mathrm{C}$, and the final composition was fully anorthite. However, the samples fired above $1200^{\circ} \mathrm{C}$ showed higher vitrification behavior (premature melting) due to the alkali content of the clay. Therefore, in the present study, the samples with sawdust addition were only fired at $1200{ }^{\circ} \mathrm{C}$.
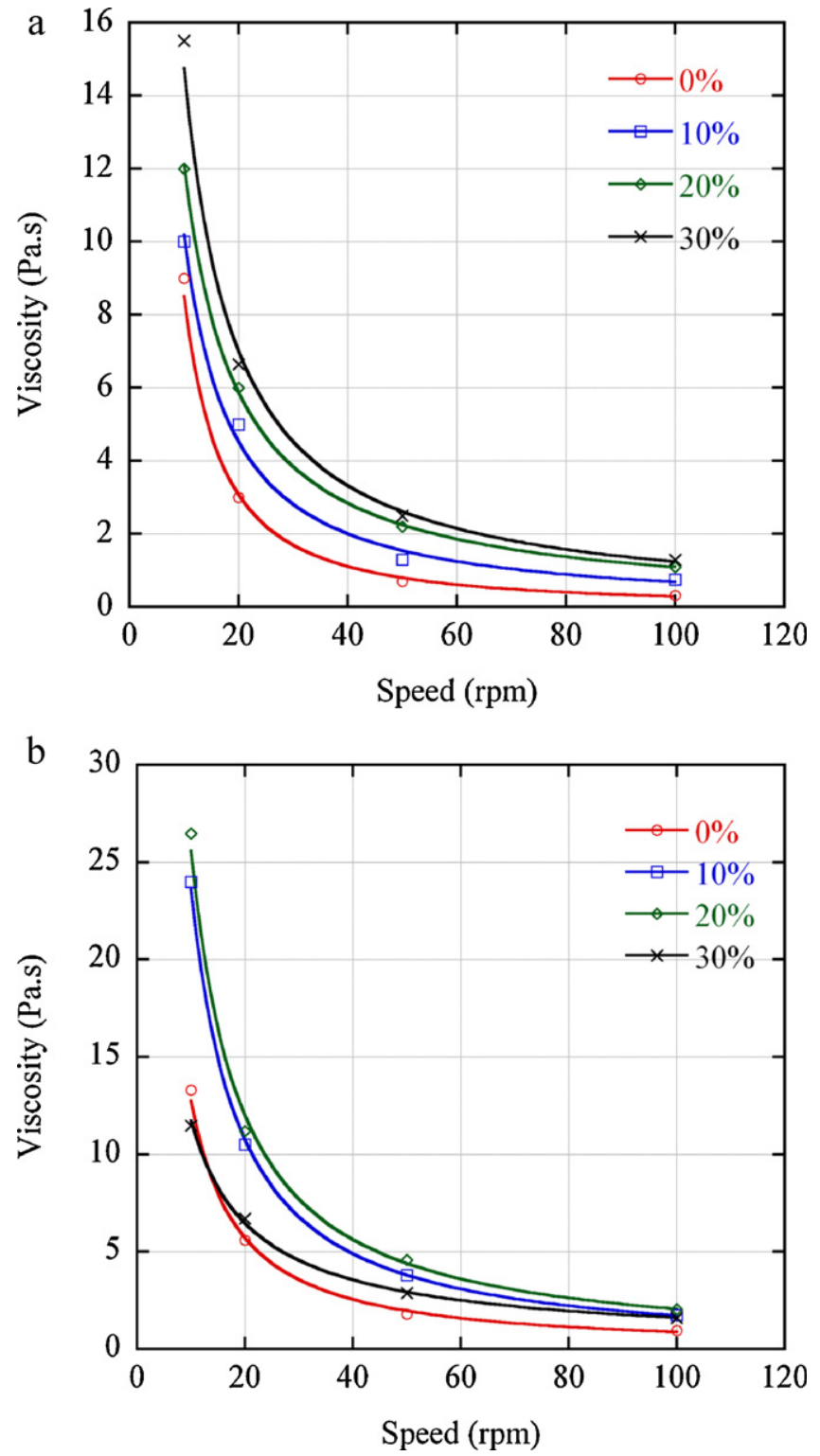

Fig. 3. Viscosity of the slurry mixtures containing (a) fireclay and (b) K244 clay with sawdust addition as a function of rotational speed of the spindle. Shear thinning rheology is evident.

Since during firing, additional heat to the kiln is expected to be supplied with the burning of sawdust.

In this study, XRD analysis results of the fired samples containing the mixtures of K244 clay and $30 \mathrm{wt} \%$ paper waste with $0-30 \%$ sawdust addition showed that anorthite could be successfully produced with minor quartz-alpha phase. Experi-

Table 1

Test results of the anorthite samples containing K244 clay and paper waste fired at $1200{ }^{\circ} \mathrm{C}$.

\begin{tabular}{llll}
\hline Physical properties & \multicolumn{2}{l}{ Mass ratio of sawdust addition } \\
\cline { 2 - 4 } & $0 \%$ & $10 \%$ & $20 \%$ \\
\hline Bulk density $\left(\mathrm{g} / \mathrm{cm}^{3}\right)$ ASTM C134 & $1.30 \pm 0.02$ & $1.09 \pm 0.02$ & $0.93 \pm 0.03$ \\
Apparent porosity (\%) ASTM C20 & $48.2 \pm 0.5$ & $55.5 \pm 0.5$ & $57.0 \pm 1.0$ \\
Thermal conductivity (W/mK) at room temperature & $0.39 \pm 0.01$ & $0.30 \pm 0.01$ & $0.87 \pm 0.06$ \\
Cold modulus of rupture (MPa) & $15.3 \pm 1.2$ & $7.04 \pm 0.8$ & $57.5 \pm 0.5$ \\
\hline
\end{tabular}



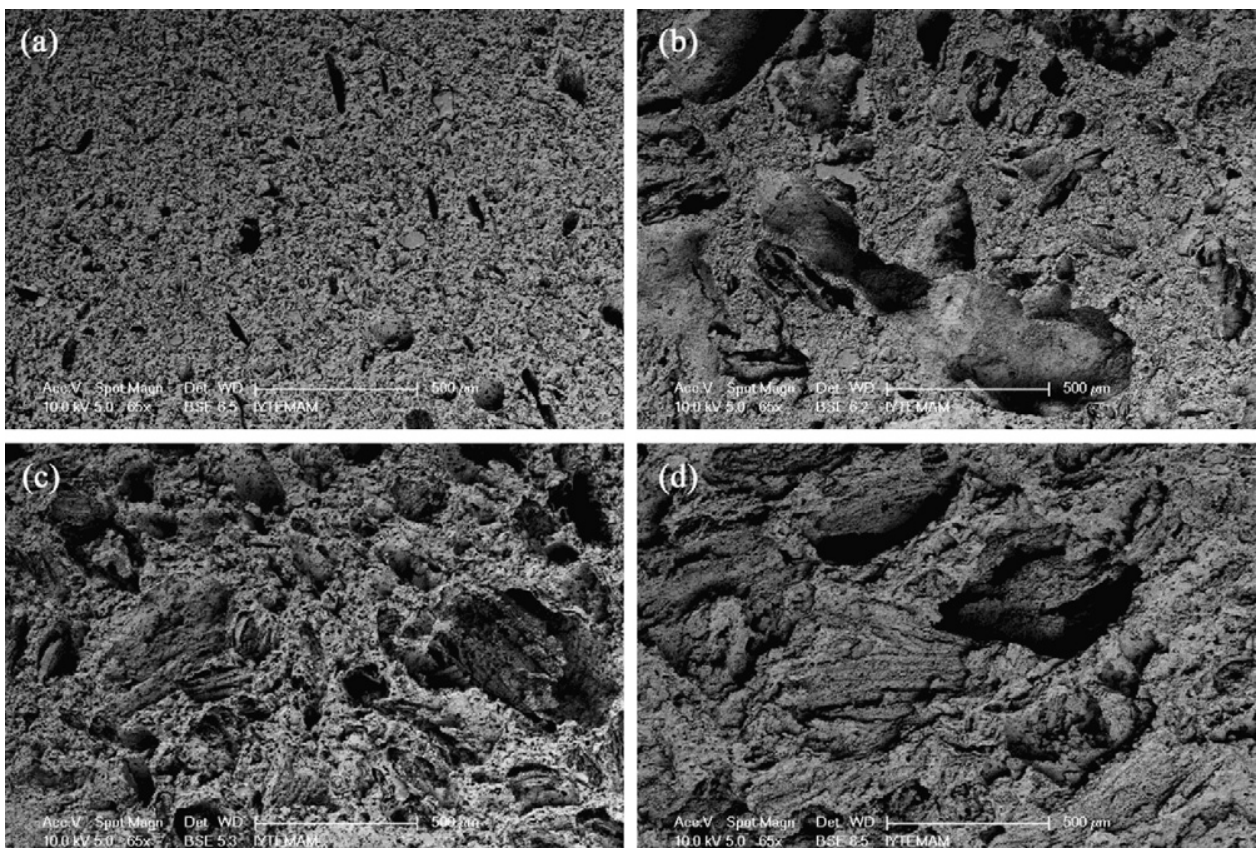

Fig. 4. The SEM images of the fired samples containing K244 clay and paper waste according to sawdust addition of (a) $0 \%$, (b) $10 \%$, (c) $20 \%$ and (d) $30 \%$.

mental results of the samples containing K244 clay and $30 \mathrm{wt} \%$ paper waste mixtures with sawdust additive are given in Table 1. The apparent porosity values of fired samples ranged from 48 to $58 \%$ with sawdust addition. The thermal conductivities and bulk densities were reduced with increasing sawdust addition. Thermal conductivity and bulk density of the product with $0 \%$ and $30 \%$ sawdust showed a reduction of $49 \%$ and $33 \%$, respectively. In other words, thermal conductivities of the samples were reduced with decreasing bulk densities. The lowest bulk density and thermal conductivity values of $0.87 \mathrm{~g} /$ $\mathrm{cm}^{3}$ and $0.20 \mathrm{~W} / \mathrm{mK}$, respectively, were achieved in samples with $30 \mathrm{wt} \%$ sawdust that were fired at $1200{ }^{\circ} \mathrm{C}$. The samples linearly shrunk up to $4.5 \%$ during firing. Modulus of rupture (MOR) results of the samples with sawdust addition is given in Table 1. Depending on the increase in the sawdust addition and

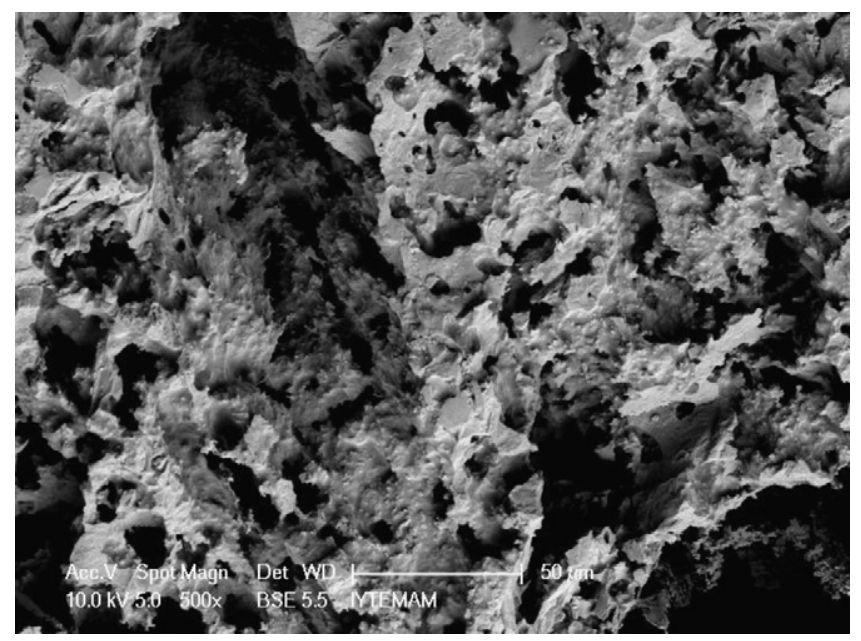

Fig. 5. The SEM image of the fired sample containing K244 clay and paper waste with sawdust addition of $20 \%$. porosity content, the MOR values of the samples progressively decreased from 15.3 to 4.5 MPa. The MOR values measured for commercial lightweight anorthite insulating firebricks (the groups 20 and 23) are between 0.7 and 1.0 MPa [23]. The strengths of samples were quite higher than that of the commercial IFBs. This case is possibly due to their vitrified structures. As can be seen from the typical SEM images of the fired samples with different amount of sawdust additive in Fig. 4, the large sized porosities of $500 \mu \mathrm{m}$ as well as small sized porosities formed in the structures. Micro-pores less than $20 \mu \mathrm{m}$ existed in the fired structures. The effect of sawdust addition was obviously observed from the microstructures. Macro-scale pores formed probably from removal of sawdust

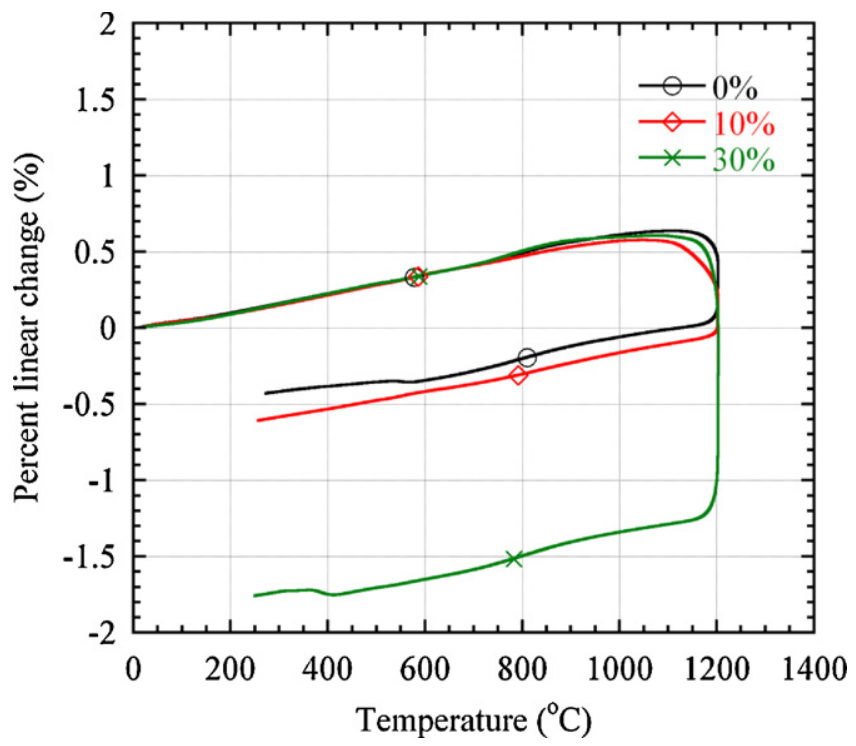

Fig. 6. Percent linear changes of the fired samples containing K244 clay and paper waste with sawdust addition. 
additives while micro-scale pores occurred most likely from removal of cellulose fibers and decomposition of calcium carbonate during firing. Formation of a highly porous structure has provided the lower thermal conductivity. Fig. 5 shows the porous structure of the fired sample with sawdust addition of $20 \%$. Fine micro-porosities can be clearly observed. SEM-EDS analysis taken from three different regions of the fired samples confirmed the composition to be in the anorthite region of $\mathrm{CaO}-$ $\mathrm{Al}_{2} \mathrm{O}_{3}-\mathrm{SiO}_{2}$ ternary system. Fired samples were rich in silica with impurities such as iron, potassium, magnesium and sodium.

Thermal dilatometer analysis was performed on the fired samples containing K244 clay to measure the coefficients of thermal expansion. Percent linear changes of the fired porous samples are shown in Fig. 6. Sample without sawdust began to shrink after about $1125^{\circ} \mathrm{C}$, while other samples shrank sooner $\left(1000-1100{ }^{\circ} \mathrm{C}\right)$ depending on the amount of sawdust addition. Total thermal expansion of the samples up to $1100{ }^{\circ} \mathrm{C}$ was around $0.6 \%$. Final reheat shrinkages for the samples were below a standard limiting value of $2 \%$ reheating shrinkage for insulating firebricks. All samples were chemically, thermally and dimensionally stable at temperatures up to $1100{ }^{\circ} \mathrm{C}$. The $\mathrm{CTE}$ of the samples were measured around $6.0 \times 10^{-6}\left(1 /{ }^{\circ} \mathrm{C}\right)$ in the temperature range $200-900{ }^{\circ} \mathrm{C}$. In order to use as an insulating ceramics, maximum operation temperature for the brick samples containing K244 clay should not exceed $1200{ }^{\circ} \mathrm{C}$.

\subsection{Fired samples containing fireclay and paper waste mixture with sawdust addition}

Fireclay (chamotte) was used to increase the refractoriness of the product by reducing the amount of glassy phase in the structure. Sawdust addition was made to help create porosity. In the previous study by the authors [15], detailed XRD analysis of the samples containing fireclay and $30 \mathrm{wt} \%$ paper waste (samples without sawdust) was presented. Samples fired at two different temperatures $\left(1200\right.$ and $\left.1400{ }^{\circ} \mathrm{C}\right)$ showed that a firing temperature of $1200{ }^{\circ} \mathrm{C}$ for this clay type was too low to produce anorthite ceramic. A firing temperature in excess of $1400{ }^{\circ} \mathrm{C}$ effectively formed anorthite. However, a firing temperature of $1400{ }^{\circ} \mathrm{C}$ is very close to the melting point of anorthite. Also, during firing, additional heat is expected to be supplied by sawdust addition. For this reason, in this current study, samples containing fireclay and $30 \mathrm{wt} \%$ paper waste with sawdust additive were fired at $1300{ }^{\circ} \mathrm{C}$.

In this study, XRD analysis of all samples showed strong anorthite peaks with minor amount of mullite but there was no
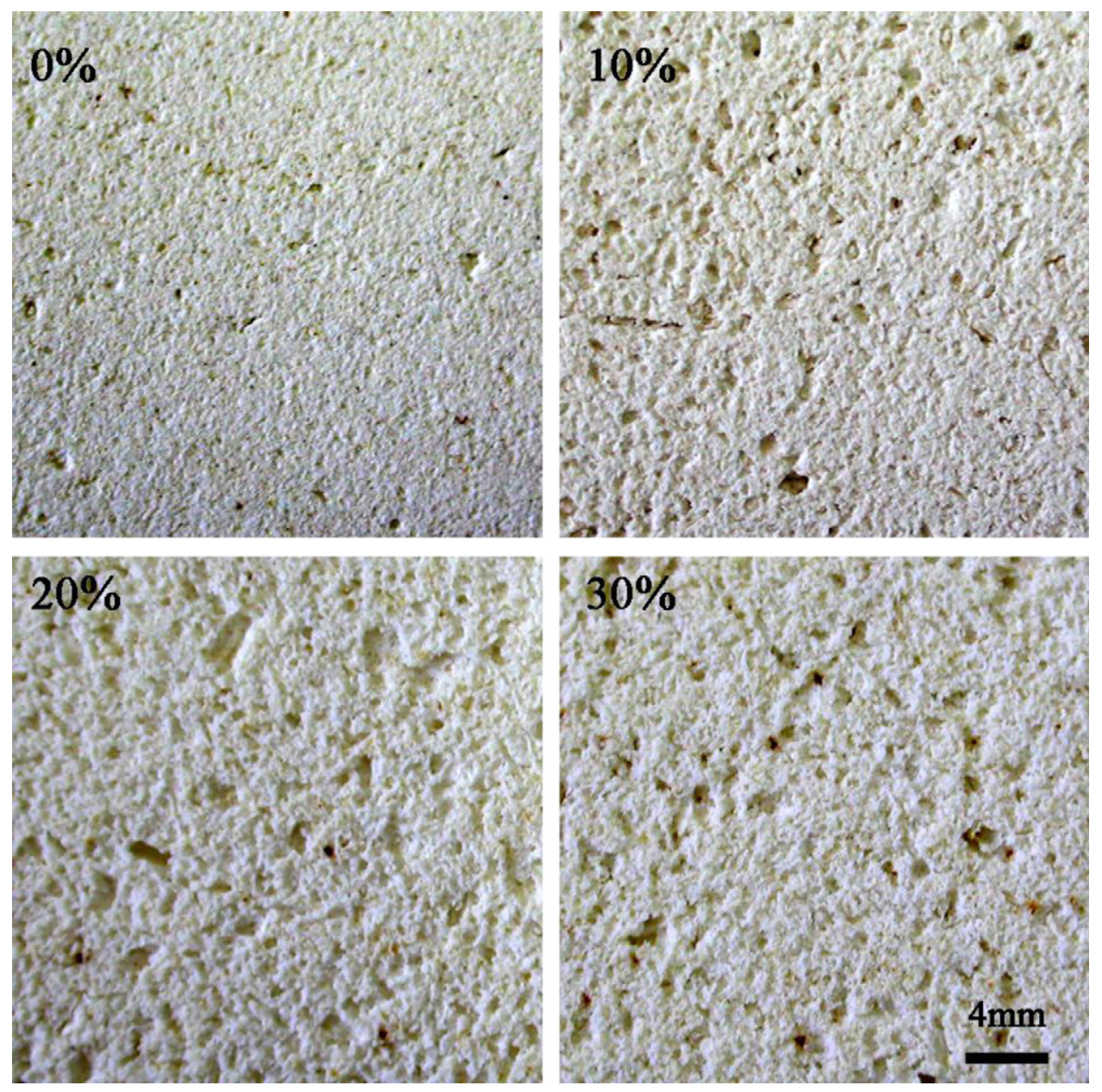

Fig. 7. Illustration of the variation of pore size of fired samples containing fireclay and paper waste according to the percentage of sawdust addition. 
difference between samples containing different amounts of sawdust. Their mineral contents resembled that of the group 23 insulating firebrick sample [23-25]. An illustration of the variation of the pore size in the fired samples as a function of sawdust addition is shown in Fig. 7. Pore sizes of the samples are generally less than $2 \mathrm{~mm}$, but there are occasionally some larger pores in the structure. Pore size distribution of the fired sample containing fireclay and paper waste mixture without sawdust addition as measured by mercury intrusion porosimetry (Fig. 8a) showed a bi-modal distribution at about $17 \mu \mathrm{m}$ and $100 \mu \mathrm{m}$ of average pore size. Pores larger than $213 \mu \mathrm{m}$ were not measured. This result was also confirmed by SEM analysis. In Fig. 8b, the SEM image of this sample indicated that pore sizes were approximately about $20 \mu \mathrm{m}$, besides there were some larger pores with dimensions of $100 \mu \mathrm{m}$ (Fig. 9a). Pore size distribution of the fired samples with sawdust addition was not measured due to their larger porosities $(>200 \mu \mathrm{m})$ beyond the detection limit of the device. In Fig. 9, the SEM images indicated that the amount and size of pores increased with increasing mass ratios of sawdust addition. Porous structures resulted from the burning of sawdust and organic matters in the paper waste, and also from the decomposition of calcium carbonate in the waste. Also, the EDS analyses were performed to find out that there was no change in chemical composition of the fired samples as a result of the addition of sawdust and that the composition was well-matching anorthite.

The physical properties such as bulk density and apparent porosity, thermal conductivity, modulus of rupture, coefficient of thermal expansion, linear reheat shrinkage and thermal shock resistance of the firebricks produced in this study were measured. Bulk density values of the firebricks ranged from 1.12 to $0.64 \mathrm{~g} / \mathrm{cm}^{3}$ depending on the mass ratio of sawdust addition (Table 2). Their bulk densities decreased with increasing sawdust addition. Apparent porosity values of the samples were measured between $57 \%$ and $74 \%$ with increasing sawdust addition. The thermal conductivity values measured at ambient temperature ranged from 0.25 to $0.13 \mathrm{~W} / \mathrm{mK}$ depending on the mass ratio of sawdust addition (Table 2). The properties of fired brick with added 20 and $30 \%$ sawdust are well-matched with the group 23 insulating firebrick $[9,23,24]$ Modulus of rupture results of the samples with sawdust addition is given in Table 2. Depending on the increase in the sawdust addition and porosity content, cold modulus of rupture of the samples progressively decreased from 2.74 to $0.61 \mathrm{MPa}$. The strength of samples was almost compatible with the commercial products [23]. In the dilatometric analysis, percent linear changes of the fired porous samples are shown in Fig. 10.

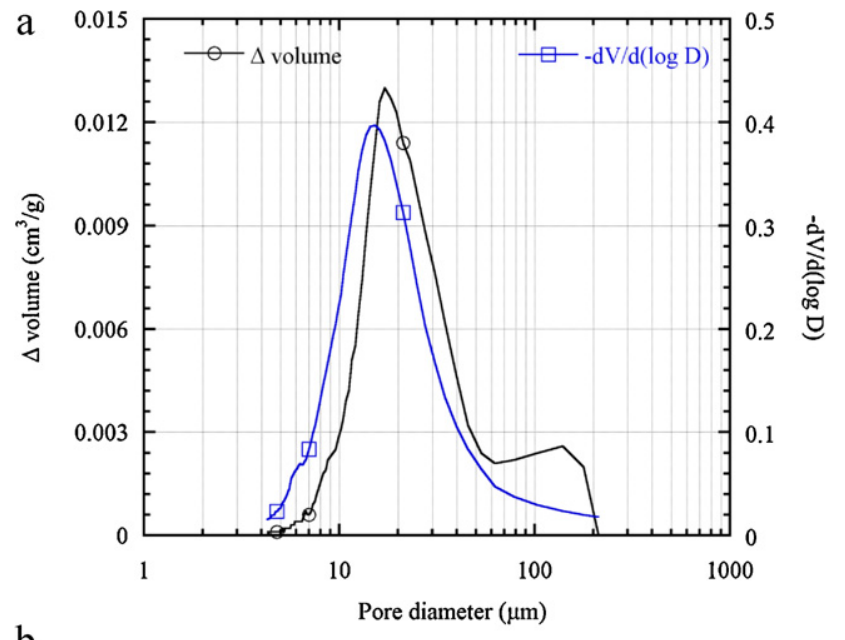

b

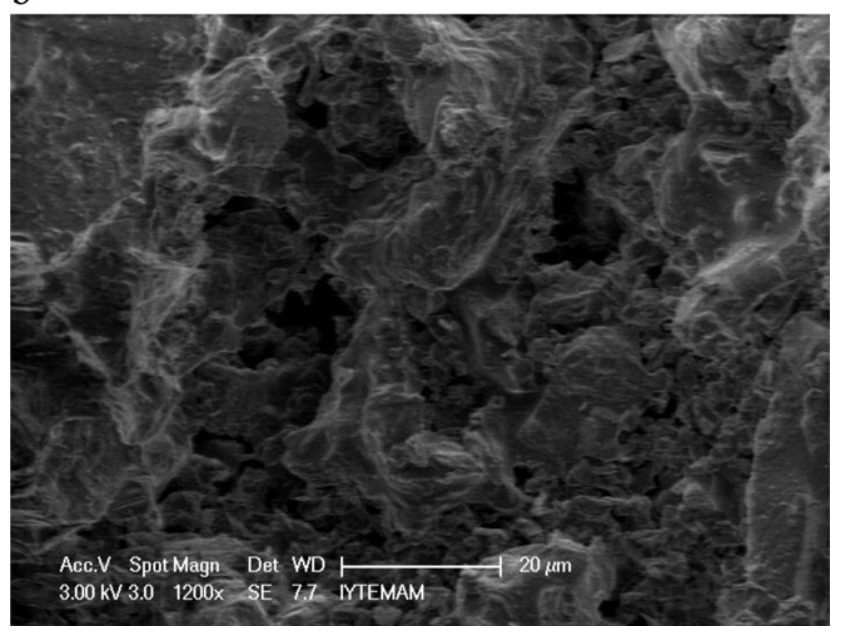

Fig. 8. (a) Pore size distribution measured by mercury intrusion method of the fired sample containing fireclay and paper waste without sawdust addition, (b) the SEM image of the fired sample without sawdust addition.

Samples without sawdust began to shrink after about $1150{ }^{\circ} \mathrm{C}$, while other samples shrank sooner $\left(1100-1150{ }^{\circ} \mathrm{C}\right)$ depending on the amount of sawdust addition. Total thermal expansion of the samples up to $1100{ }^{\circ} \mathrm{C}$ varied from 0.5 to $0.7 \%$. Final reheat shrinkages for the samples with $0,10,20$ and $30 \%$ sawdust was around $0.2,0.7,1.5$ and $0.6 \%$, respectively. All samples were chemically, thermally and dimensionally stable at temperatures up to $1100{ }^{\circ} \mathrm{C}$. The safe operating temperature may be established by the softening onset point on the dilatometric curve. The bricks produced in this study may be safely used up to $1100{ }^{\circ} \mathrm{C}$. Coefficients of thermal expansion (CTE) of the samples were measured around $6.7 \times 10^{-6}\left(1 /{ }^{\circ} \mathrm{C}\right)$ in the

Table 2

Results of anorthite samples containing fireclay and paper waste fired at $1300{ }^{\circ} \mathrm{C}$.

\begin{tabular}{|c|c|c|c|c|}
\hline \multirow[t]{2}{*}{ Physical properties } & \multicolumn{4}{|c|}{ Mass ratio of sawdust addition } \\
\hline & $0 \%$ & $10 \%$ & $20 \%$ & $30 \%$ \\
\hline Bulk density $\left(\mathrm{g} / \mathrm{cm}^{3}\right)$ ASTM C134 & $1.12 \pm 0.04$ & $0.92 \pm 0.02$ & $0.75 \pm 0.01$ & $0.64 \pm 0.00$ \\
\hline Apparent porosity (\%) ASTM C20 & $56.9 \pm 0.5$ & $64.7 \pm 0.4$ & $71.8 \pm 0.2$ & $74.1 \pm 0.1$ \\
\hline Thermal conductivity $(\mathrm{W} / \mathrm{mK})$ at room temperature & $0.25 \pm 0.00$ & $0.19 \pm 0.01$ & $0.15 \pm 0.01$ & $0.13 \pm 0.00$ \\
\hline Cold modulus of rupture (MPa) & $2.74 \pm 0.23$ & $1.84 \pm 0.11$ & $1.1 \pm 0.1$ & $0.61 \pm 0.1$ \\
\hline
\end{tabular}



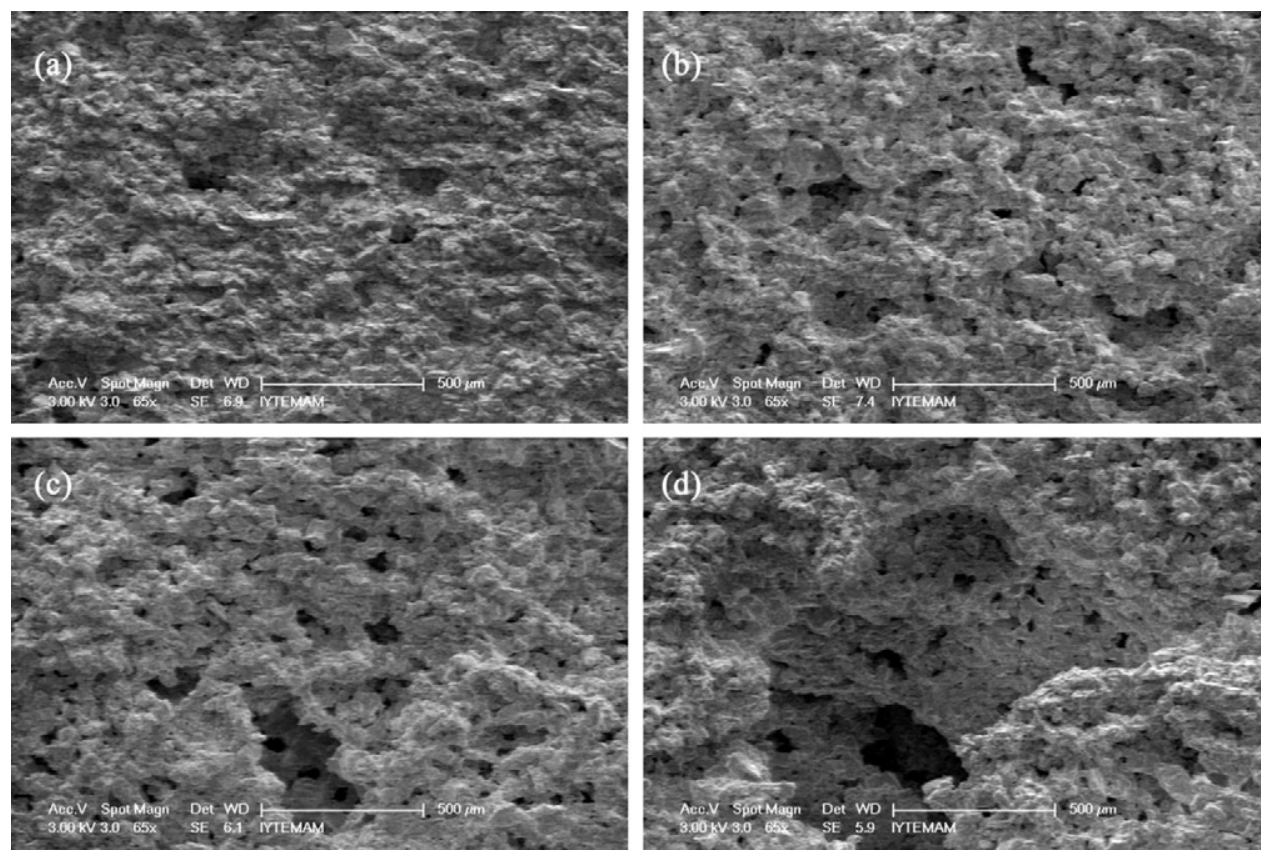

Fig. 9. The SEM images of the fired samples containing fireclay and paper waste according to the mass ratio of sawdust addition: (a) $0 \%$, (b) $10 \%$, (c) $20 \%$ and (d) $30 \%$.

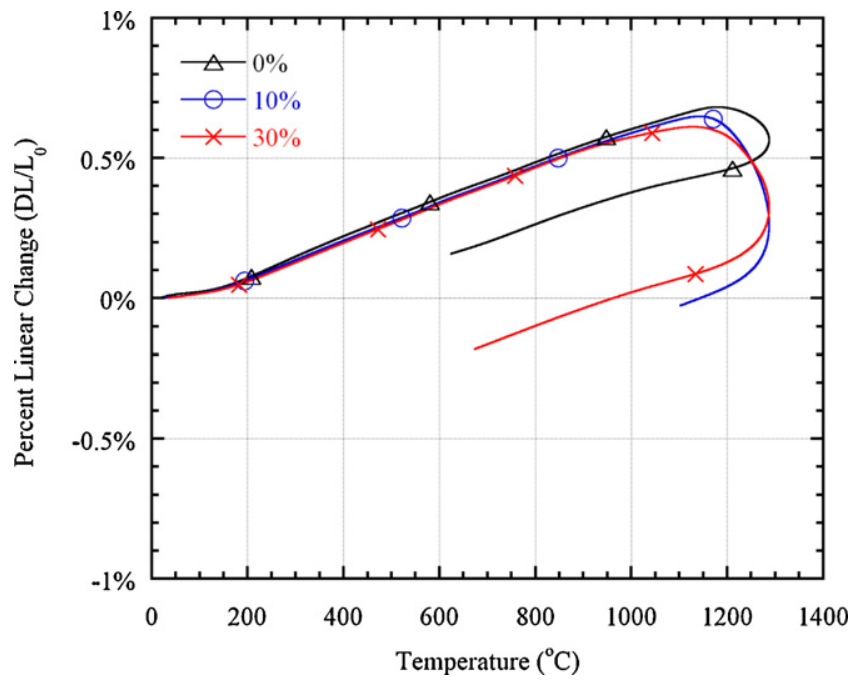

Fig. 10. Percent linear changes of the fired samples containing fireclay and paper waste according to the ratio of sawdust additives.

temperature range $200-900{ }^{\circ} \mathrm{C}$. Finally, the thermal shock tests performed on samples showed that their resistance to repeated five heating and cooling cycles was good. Samples were found to be intact after the test.

\section{Conclusions}

In this study, the production of porous and lightweight anorthite based insulating ceramics from mixtures of different types of clay (K244 clay and fireclay), recycled paper processing waste and sawdust addition was investigated. It was concluded that the recycled paper processing wastes could be used as a suitable alternative raw material source for production of porous anorthite ceramics due to their organic and inorganic content. The reaction between calcium oxide from paper waste and aluminum silicate from clays resulted in the formation of anorthite $\left(\mathrm{CaO} \cdot \mathrm{Al}_{2} \mathrm{O}_{3} \cdot 2 \mathrm{SiO}_{2}\right)$ with a minor secondary phase. Suitability of clay 244 with alkalis and fireclay in the manufacturing of anorthite based lightweight insulating ceramics was also evaluated. Sawdust addition into the mixtures with anorthite composition contributed to increase porosity of the samples.

Porous and lightweight anorthite ceramics from the mixtures of fireclay and paper waste with sawdust addition were successfully produced. It was concluded that their bulk densities ranged from 1.12 to $0.64 \mathrm{~g} / \mathrm{cm}^{3}$, and also their thermal conductivities varied from 0.25 to $0.13 \mathrm{~W} / \mathrm{mK}$ depending on their porosity content. Their strength values were sufficient for use as insulating firebrick. Physical properties of the samples with 20 and $30 \%$ sawdust are compatible with that of the group 23 insulating firebricks. In the samples with $\mathrm{K} 244$ clay, firing temperature of $1200{ }^{\circ} \mathrm{C}$ was sufficient to produce a porous anorthite ceramic due to the presence of alkalis in the clay. Their bulk densities and thermal conductivities were higher than the samples containing fireclay. For all samples, the reheating shrinkage values were below a standard limiting value. The products were stable at high temperatures up to $1100{ }^{\circ} \mathrm{C}$. Finally, the usable products were produced by the use of an otherwise useless recycled paper processing waste.

\section{Acknowledgements}

Authors would like to thank to Levent Kağıt A.Ş., Kalemaden and Eczacıbaşı Esan (in Turkey) for providing the raw materials. Thanks are also due to the Center for Materials Research (IYTE-MAM) and the Geothermal Energy Research and Application Center (IYTE-JEOMER) for their helps in some measurements and analysis. 


\section{References}

[1] Handbook of Refractory Practice, Harbison-Walker Refractories Company, 2005.

[2] A.L. Yurkov, L.M. Aksel'rod, Properties of heat-insulating materials (a review), Refractories and Industrial Ceramics 46 (3) (2005) 170-174.

[3] L.A. Dergaputskaya, A.N. Gaodu, L.G. Litvin, Anorthite lightweight refractories for service in carbon-containing media, Refractories and Industrial Ceramics 21 (7) (1980) 366-368.

[4] E. Horie, T. Saeki, S. Oosawa, H. Hisaka, N. Tanetani, Process for making heat insulating firebricks, U.S. Patent: US 4,307,199 (1981).

[5] O. Koronthalyova, P. Matiasovsky, Pore structure and thermal conductivity of burnt clay bricks, in: Leja Jozef (Ed.), Thermophysics 2007, Meeting of the Thermophysical Society, Vydavatel'stvo STU, Bratislava, (2007), pp. $100-106$.

[6] Y.N. Kryuchkov, V.P. Mineev, S.V. Troyanskaya, V.V. Tkach, A heatinsulating lightweight material, Glass and Ceramics 56 (5-6) (1999) $158-159$.

[7] A.A. Pirogov, V.P. Rakina, M.M. Mirak'yan, N.V. Volkov, Anorthite insulating refractory, Refractories and Industrial Ceramics 11 (5) (1970) 303-307.

[8] S.A. Suvorov, V.V. Skurikhin, Vermiculite - a promising material for hightemperature heat insulators, Refractories and Industrial Ceramics 44 (3) (2003) 186-193.

[9] ASTM C155-97, Standard Classification of Insulating Firebrick, ASTM International, West Conshohocken, PA, 2002.

[10] B. Ahmadi, W. Al-Khaja, Utilization of paper waste sludge in the building construction industry, Resources, Conservation and Recycling 32 (2) (2001) 105-113.

[11] D.A. Brosnan, Low density ceramics produced from paper recycling residuals B1, US 6,569,797 (2003).

[12] S. Dasgupta, S.K. Das, Paper pulp waste - a new source of raw material for the synthesis of a porous ceramic composite, Bulletin of Materials Science 25 (5) (2002) 381-385.
[13] İ. Demir, M.S. Baspınar, M. Orhan, Utilization of kraft pulp production residues in clay brick production, Building and Environment 40 (11) (2005) 1533-1537.

[14] M. Sutcu, S. Akkurt, The use of recycled paper processing residues in making porous brick with reduced thermal conductivity, Ceramics International 35 (7) (2009) 2625-2631.

[15] M. Sutcu, S. Akkurt, Utilization of recycled paper processing residues and clay of different sources for the production of porous anorthite ceramics, Journal of the European Ceramic Society 30 (8) (2010) 1785-1793.

[16] ASTM Standard C134-95, Standard Test Methods for Size, Dimensional Measurements, and Bulk Density of Refractory Brick and Insulating Firebrick, ASTM International, West Conshohocken, PA, 2005.

[17] ASTM Standard C20, Standard Test Methods for Apparent Porosity, Water Absorption, Apparent Specific Gravity, and Bulk Density of Burned Refractory Brick and Shapes by Boiling Water, ASTM International, West Conshohocken, PA, 2005.

[18] ASTM C133-97, Standard Test Methods for Cold Crushing Strength and Modulus of Rupture of Refractories, ASTM International, West Conshohocken, PA, 2003.

[19] ASTM C1171-96, Standard Test Method for Quantitatively Measuring the Effect of Thermal Shock and Thermal Cycling on Refractories, ASTM International, West Conshohocken, PA, 2003.

[20] http://www.esan.com.tr.

[21] http://www.kalemaden.com.tr.

[22] P. Kalita, G. Mohan, G. Pradeep Kumar, P. Mahanta, Determination and comparison of kinetic parameters of low density biomass fuels, Journal of Renewable and Sustainable Energy 1 (2) (2009) 1-12, 023109.

[23] http://www.thermalceramics.com/pdfsuploaded/datasheets/americas/ 114-3.pdf (accessed May 2009).

[24] D.A. Brosnan, Alumina-silica brick, in: C.A. Schacht (Ed.), Refractories Handbook, Marcel Dekker Inc., New York, 2004, pp. 79-107.

[25] M. Sutcu, The use of paper processing residues in the development of ceramics with improved thermal insulation properties, $\mathrm{PhD}$ Thesis, 2010, Izmir Institute of Technology, Izmir. 